\title{
Transient vertical loading of model suction caissons in a pressure chamber
}

\section{R. B. KELLY*, G. T. HOULSBY ${ }^{\dagger}$ and B. W. BYRNE ${ }^{\dagger}$}

Vertical monotonic and cyclic loading tests on model suction caissons have been carried out to explore conditions relevant to the design of multiple-footing foundations for offshore wind turbines. The tests were conducted in a pressurised chamber, which simulates up to $20 \mathrm{~m}$ of water depth, to investigate the effect of cavitation on the ultimate tensile response of the caisson. Cyclic loading tests were also conducted at elevated pressures. Data from cyclic tests are presented to compare the response of caissons subjected to varying ambient pressures and rates of loading. The ambient pressure had little effect on the cyclic response. Faster rates of loading generated larger pressures beneath the lid of the caisson and increased the load-displacement stiffness. The ultimate tensile capacity was significantly affected by the ambient pressure and rate of loading. Implications for the design of offshore caisson foundations are discussed.

KEYWORDS: bearing capacity; footings/foundations; model tests; offshore engineering; repeated loading; sands
Des tests de chargement monotones et cycliques ont été réalisés sur des caissons à succions modèles pour évaluer les conditions appropriées à la conception d'éoliennes offshore à soutènements multiples. Ces essais ont été effectués dans une chambre pressurisée qui peut simuler une profondeur d'eau allant jusqu'à 20 mètres, pour étudier l'effet de la cavitation sur la résistance ultime en tension du caisson. Les essais de chargement cycliques ont également été réalisés à des pressions élevées. Les données des essais cycliques sont présentées pour comparer les réponses des caissons exposés à des pressions ambiantes et taux de chargement variés. La pression ambiante ne montre que peu d'effet sur la réponse cyclique. Des taux de chargement plus rapides génèrent des pressions plus importantes en dessous du couvercle du caisson et augmentent la rigidité charge-déplacement. La pression ambiante et le taux de chargement influent significativement sur la capacité ultime en tension. Les conséquences de ces résultats en terme de conception de fondations de caisson offshore sont ici discutées.

\section{INTRODUCTION}

The offshore wind energy industry is a rapidly expanding sector in the UK, with over 500 wind turbines planned for construction within the next few years and up to 2000 turbines by the year 2010. The first developments are being constructed near-shore, in water up to about $15 \mathrm{~m}$ deep, and will be founded mainly on large 'mono-piles'. The cost of mono-pile foundations is a significant part of the total cost of an offshore wind turbine installation. Mono-piles are the preferred technology, as they have been extensively proven offshore. However, when wind farms are built in greater water depths, alternative designs may be necessary. The stiffness of the subsea support structure and foundation system will be critical to the overall design, as the turbine superstructure is dynamically sensitive. To increase the stiffness of the support structure it is likely that multiple-footing designs will be used, consisting of piles or alternatives. It is likely that multiple-pile foundations may not be the most economic solution in some instances. An alternative is to use a tetrapod jacket structure incorporating 'suction caisson' footings at each corner (Byrne \& Houlsby, 2003). Fig. 1 shows a typical tetrapod, with the salient dimensions. Similar arrangements have been used offshore as foundations for a small number of fixed platforms (Tjelta 1994, 1995; Bye et al., 1995).

A key feature of offshore wind turbine structures is that, for their size, they are relatively light, yet they are subjected

Manuscript received 8 April 2005; revised manuscript accepted 31 October 2006

Discussion on this paper closes on 1 June 2007, for further details see p. ii.

${ }^{*}$ Coffey Geotechnics Pty Ltd, Sydney, NSW, Australia (formerly Research Assistant, University of Oxford, UK).

$\dagger$ Department of Engineering Science, University of Oxford, UK.

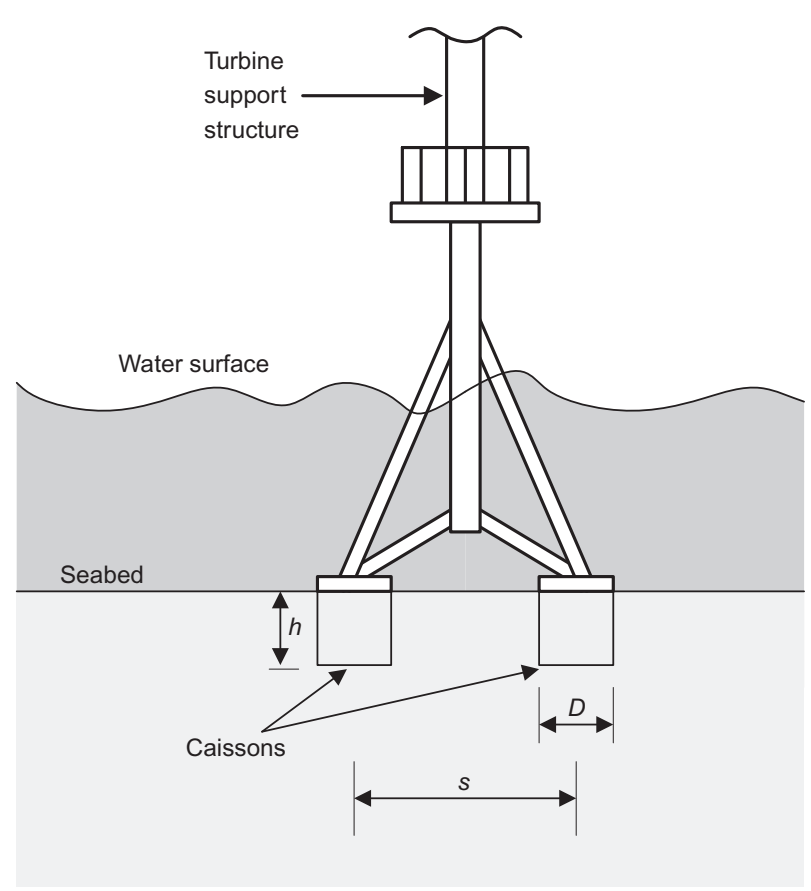

Fig. 1. Configuration and salient dimensions of tetrapod suction caisson foundation for offshore wind turbine

to large horizontal forces and overturning moments from wind and waves. In the case of a tetrapod foundation, the overturning moment is principally carried by 'push-pull' action by opposing footings, and it is the variation of vertical load, and in particular the possibility of tension on a footing, that is most important (Byrne \& Houlsby, 2003). The design needs are to select an appropriate diameter $D$ 
and depth $h$ of the caisson, as well as the spacing $s$ of the foundations (Fig. 1). Quantifying the allowable tension on the caisson is vital for designing the size of the structure. A research project (Byrne et al., 2002) has been carried out to explore the design of suction caissons under various loading conditions, especially the vertical loading relevant to multiple-footing structures. Design guidelines for vertical loading are developed based principally on laboratory tests on smallscale model caissons (Byrne \& Houlsby, 2002; Kelly et al., 2003, 2004, 2006a), verified by field scale testing (Houlsby et al., 2006). This paper reports selected vertical loading data from laboratory tests, with the following features.

(a) A computer-controlled hydraulic actuator has been used, so that cyclic loading paths can be applied at high loading rates. The model used here is significantly larger than in tests reported by Byrne \& Houlsby (2002), and the loads are correspondingly larger too.

(b) Two sands of different gradings have been used, so that a range of behaviour, from drained to approaching undrained, could be obtained. This compares with the oil-saturated fine sand used by Byrne \& Houlsby (2002), in which the foundation response was closer to undrained conditions than to drained.

(c) Tests were carried out in a pressurised container, so that the effect of the water depth could be simulated. This is important because the pressure (relative to seabed pressure) at which cavitation of the pore fluid occurs will be dependent on the ambient water pressure. The principle of effective stress guarantees that altering the water pressure should of course have no impact on the response of the soil unless, when the footing is under tension and/or the soil is dilating rapidly, the suction in the pore fluid becomes sufficiently large for cavitation to occur. The development of suctions in dilative sand under undrained conditions is discussed by McManus \& Davis (1997). The suctions will be limited by the cavitation pressure of the fluid, which may therefore influence the overall foundation response. Tests were carried out at atmospheric pressure and at $200 \mathrm{kPa}$ above atmospheric (i.e. simulating a water depth of $20 \mathrm{~m}$ ) to examine the effect of the cavitation pressure.

For further details of the testing programme, testing equipment and procedures, and comprehensive records of individual tests, see Kelly et al. (2006b).

\section{EQUIPMENT AND TESTING PROCEDURES}

The pressure chamber, loading apparatus and model caisson are shown in Figs 2 and 3. The chamber is a watertight cylinder, $1 \mathrm{~m}$ in diameter and $1 \mathrm{~m}$ high. A hydraulically powered actuator, fixed to the lid of the chamber, provided either load- or displacement-controlled vertical loading on the model caisson. The caisson was located beneath the lid of the pressure chamber and fixed to the actuator via a ram passing through a gland in the chamber lid. The model caisson was $280 \mathrm{~mm}$ in diameter, had a skirt length of $180 \mathrm{~mm}$ and wall thickness $3 \cdot 125 \mathrm{~mm}$. A custom-built waterproof load cell was fixed on top of the caisson to record the vertical load. A second load cell was located outside the pressure chamber, recording the loads applied by the actuator and used for feedback for actuator control. A comparison of the loads from the two cells provided an indication of the friction on the ram passing through the gland. Frictional loads of several kilonewtons were commonly observed. Discrepancies between the quoted nominal values of the mean and cyclic loads (measured and controlled by the external

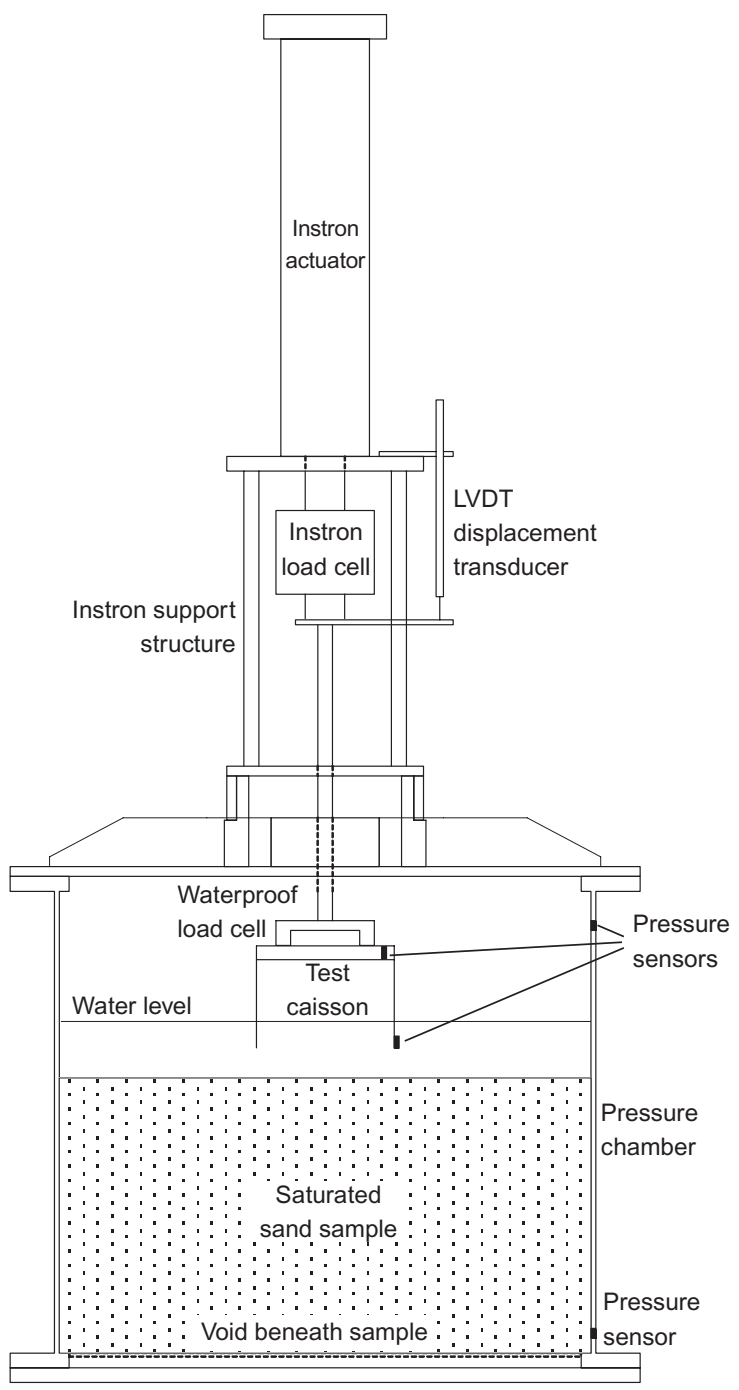

Fig. 2. Pressure vessel, loading apparatus and instrumentation

load cell) and the load data presented in the figures (measured by the internal load cell) are due to friction on the ram.

Pressure sensors were attached to the caisson to record water pressures beneath the caisson lid and at the skirt tip. The latter was measured with an Entran micro-miniature sensor placed flush with the base of the skirt, in a $3 \mathrm{~mm}$ diameter aluminium tube that was glued into a groove milled into the inside of the skirt wall. A pressure sensor was also fixed in the chamber wall above water level to record the ambient pressure. The caisson displacement was measured by an LVDT fixed to the ram outside the pressure chamber. The actuator also incorporated an integral displacement transducer. The data were recorded using PC-based data acquisition systems, and the actuator was controlled using software supplied by Instron.

Two test beds of saturated sand were constructed in the chamber, so that the effects of drainage on foundation response could be explored. One used Redhill 110, a finegrained silica sand. The other used Oakamoor HPF5, a sandy silt artificially created by crushing, which creates highly angular particles, leading to high frictional strengths. The particle size distributions of the sands are given in Fig. 4. Maximum and minimum void ratios, and permeabilities estimated by Houlsby et al. (2005) for each material, are shown in Table 1. The permeabilities were estimated using Hazen's empirical correlation, and therefore indicate only approximate relative values. Peak friction angles were estimated from undrained triaxial tests for the Redhill 110 sand 


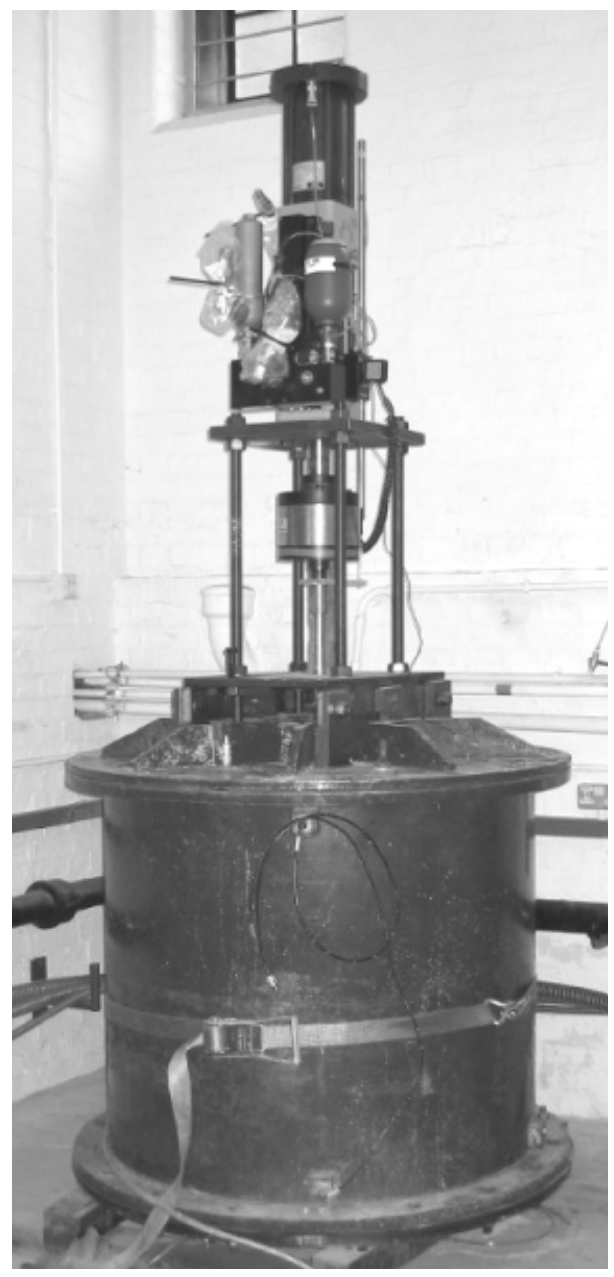

(a)

Fig. 3. (a) Pressure vessel; (b) model caisson

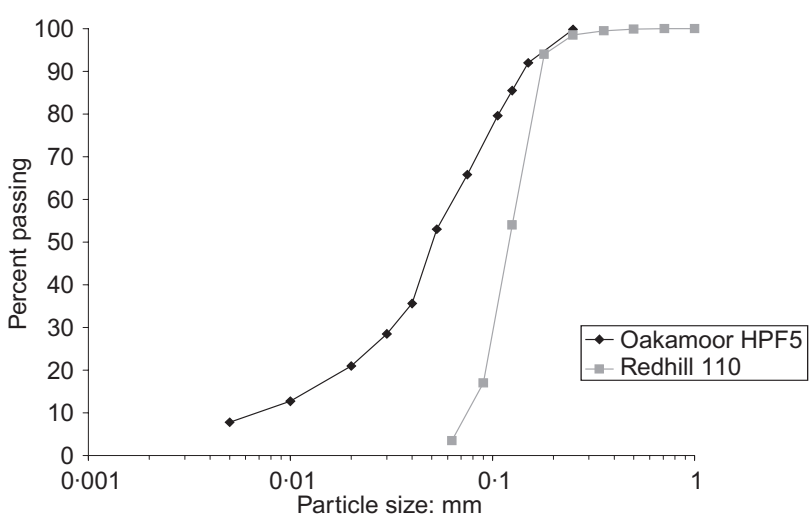

Fig. 4. Particle size distribution for Redhill 110 and Oakamoor HPF5 sands

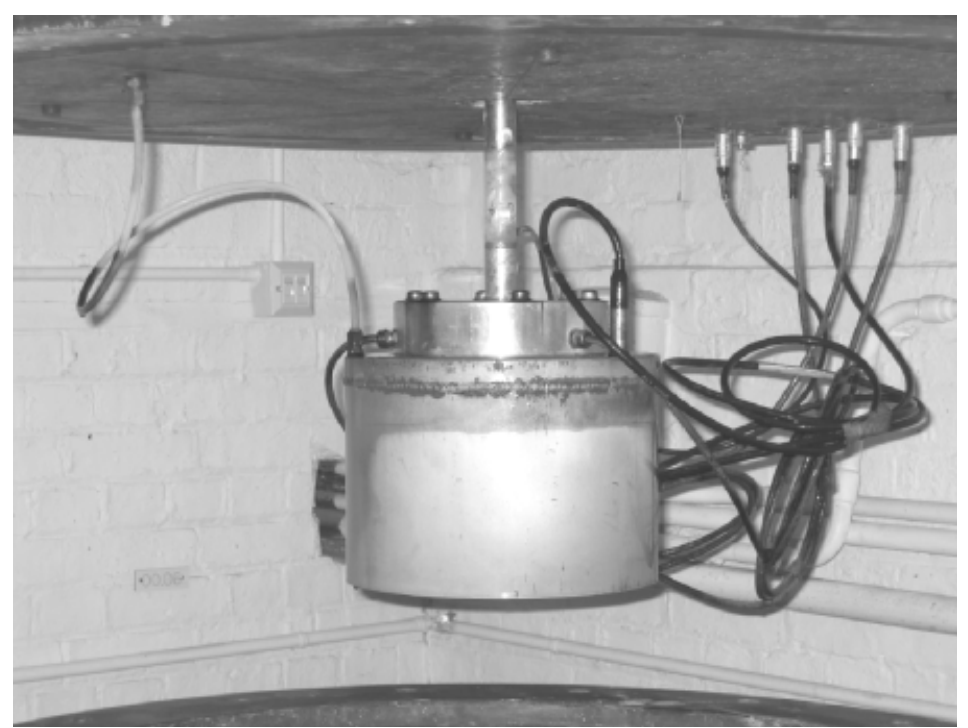

(b)
$\left(R_{\mathrm{D}}=75 \%\right)$ as $46^{\circ}$ for a test starting from $p^{\prime}$ of approximately $10 \mathrm{kPa}$, reducing to about $41^{\circ}$ for a similar test starting from $p^{\prime}$ of $100 \mathrm{kPa}$. Undrained triaxial testing on the HPF5 sand indicated a peak friction angle of $48^{\circ}$ for a test starting from $p^{\prime}$ of approximately $50 \mathrm{kPa}$. Estimated critical state angles are $36^{\circ}$ for Redhill 110 and possibly slightly higher for the HPF5 sand.

The Redhill 110 test bed was constructed in two stages. Initially a filter layer, approximately $80 \mathrm{~mm}$ thick, of Leighton Buzzard 16-30 silica sand was placed. Redhill 110 was then placed over the filter layer. The sample was saturated by flushing water through it from the base of the chamber. Any remaining air was removed by applying a vacuum to the top of the pressure chamber and flushing carbon dioxide through the bed from the bottom. The HPF5 test bed was constructed in a different manner, to minimise the hazard from fine silica dust raised during placement of this sand.

Table 1. Properties of Redhill 110 and Oakamoor HPF5 sands

\begin{tabular}{l|c|c|c}
\hline Material & $\begin{array}{c}\text { Maximum void } \\
\text { ratio }\end{array}$ & $\begin{array}{c}\text { Minimum void } \\
\text { ratio }\end{array}$ & $\begin{array}{c}\text { Estimated permeability: } \\
\mathrm{m} / \mathrm{s}\end{array}$ \\
\hline Redhill 110 & 1.037 & 0.547 & $5.0 \times 10^{-4}$ \\
Oakamoor HPF5 & 1.014 & 0.467 & $5.0 \times 10^{-7}$ \\
\hline
\end{tabular}


The water was drained from the pressure chamber and most of the Redhill 110 removed. A $10 \mathrm{~mm}$ layer of Redhill 110 was left to provide an additional filter above the $80 \mathrm{~mm}$ filter of Leighton Buzzard 16-30 sand. The tank was then filled with water, and the HPF5 sand was placed through the water into the tank. Repeated vibration of the pressure chamber was used to remove air from the sample.

Each test bed was prepared to the required density by first loosening the sand by applying an upward hydraulic gradient. The bed was then densified by placing a flat steel plate on top of the soil, to provide a surcharge, and applying vibration to the walls of the chamber. The relative density of the Redhill 110 samples was $80-82 \%$, corresponding to submerged unit weights of $9.8-9.9 \mathrm{kN} / \mathrm{m}^{3}$. The HPF5 samples had relative densities from $53 \%$ to $73 \%$, corresponding to submerged unit weights of $9 \cdot 4-10 \cdot 0 \mathrm{kN} / \mathrm{m}^{3}$.

The caissons were installed by slowly pushing them into the test bed. A vent valve in the caisson lid was open to prevent water pressure building up inside the caisson (which might cause piping in the sand). The caisson was installed at a rate of $0.1 \mathrm{~mm} / \mathrm{s}$ in Redhill 110 and $0.05 \mathrm{~mm} / \mathrm{s}$ in HPF5, until the lid of the caisson came into contact with the water, when the rate was reduced to $0.02 \mathrm{~mm} / \mathrm{s}$. Typically the lid of the caisson made contact with the sand at a vertical load of about $2 \mathrm{kN}$ (average vertical stress, i.e., load/footing diameter, of $32 \mathrm{kPa}$ ), and the installation was continued until a load of $5 \mathrm{kN}(81 \mathrm{kPa})$ was reached, to ensure firm contact with the sand surface. At this stage, for tests in Redhill 110, the installation was paused and a slight increase in ambient pressure was applied to the chamber to purge air from within the caisson through a drainage line. This was not necessary for tests in HPF5, as there was a slight flow of water continuously through the drainage line during installation. Installation was then continued until a load of $35 \mathrm{kN}$ $(568 \mathrm{kPa})$ was applied. Data from the installation of the caissons in Redhill 110 sand have been presented by Kelly et al. (2003), who also present equations predicting the loads required for installation, taking into account the enhancement of skin friction due to down-drag of the sand adjacent to the caisson (Houlsby and Byrne, 2005). The vent valve to the caisson was then closed, and cyclic loading and/or ultimate tensile loading was applied to the caisson. Brief details of the tests presented in this paper are given in Table 2, and comprehensive descriptions of all 27 tests are given by Kelly et al. (2006b). The cyclic loads applied to the caisson during the multiple-amplitude cyclic tests are given in Table 3.

\section{TEST RESULTS}

Multiple-amplitude cyclic loading

The cyclic test data are presented in terms of vertical stress, computed as the applied vertical load divided by the cross-sectional area of the caisson. Unless stated otherwise, the water pressure refers to that measured beneath the caisson lid.

Vertical stress and water pressure during a multiple-amplitude cyclic loading test at $1 \mathrm{~Hz}$ in Redhill 110 sand are shown in Fig. 5. The data show that the displacement per cycle increases with stress amplitude and is greatest in the first cycle of each set at any stress amplitude (details are discussed further below). During the last two cyclic load packets the stiffness reduces significantly as the minimum load approaches $0 \mathrm{kN}$, and becomes very small once the vertical load becomes tensile. During the last packet of cycles the target loads were $35 \pm 40 \mathrm{kN}(569 \pm 650 \mathrm{kPa})$, indicating a target tensile load of $-5 \mathrm{kN}$, corresponding to an average tensile stress of $-81 \mathrm{kPa}$. In fact this could not be attained, with the maximum tensile stress recorded in any test being $-32 \mathrm{kPa}$. Note particularly that, although tensile stresses are accompanied by large upward displacements, over the course of an entire load cycle the net displacement was downwards. These observations are consistent with those reported by Byrne and Houlsby (2002).

Comparison of Figs 5 and 6 shows that the increase in pressure in Test 6 by $200 \mathrm{kPa}$ has had virtually no effect on the vertical stress-deformation response, but has just

Table 2. Test details

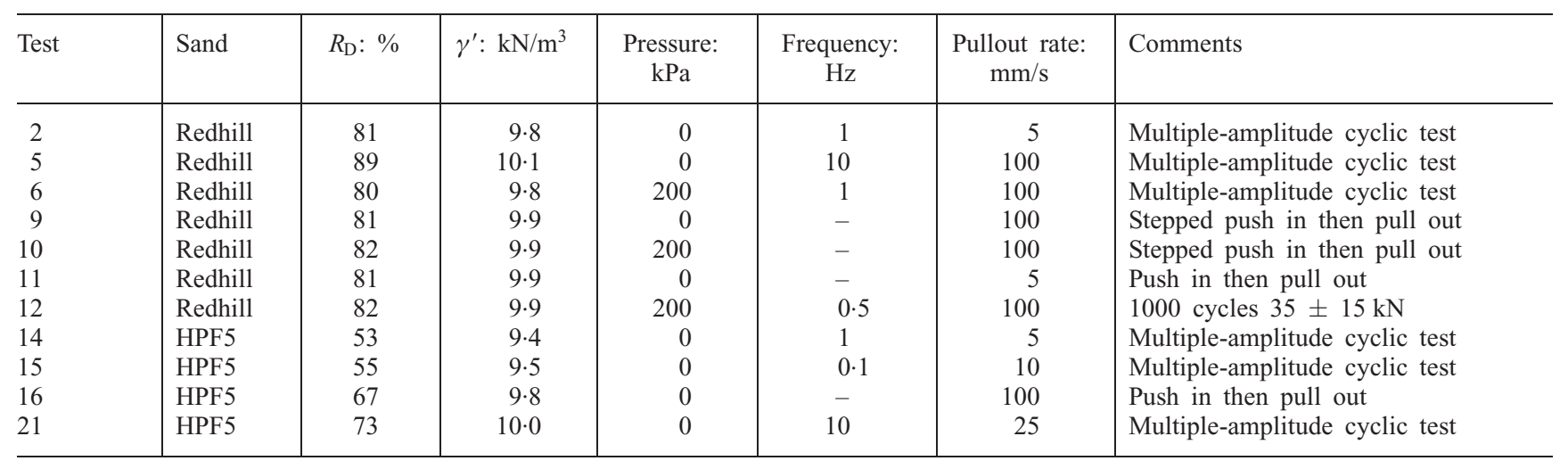

Table 3. Nominal cyclic loads applied to the model caisson

\begin{tabular}{l|c|c|c}
\hline Cycle packet & Number of cycles & Amplitude: kN & Amplitude: kPa \\
\hline 1 & 10 & 10 & 162 \\
2 & 10 & 20 & 325 \\
3 & 10 & 40 & 650 \\
4 & 10 & 60 & 974 \\
$5^{*}$ & 5 & 80 & 1137 \\
$6^{*}$ & 5 & 8099 \\
\hline
\end{tabular}

* Tests 5 and 6 have 10 cycles in packets 5 and 6 . 


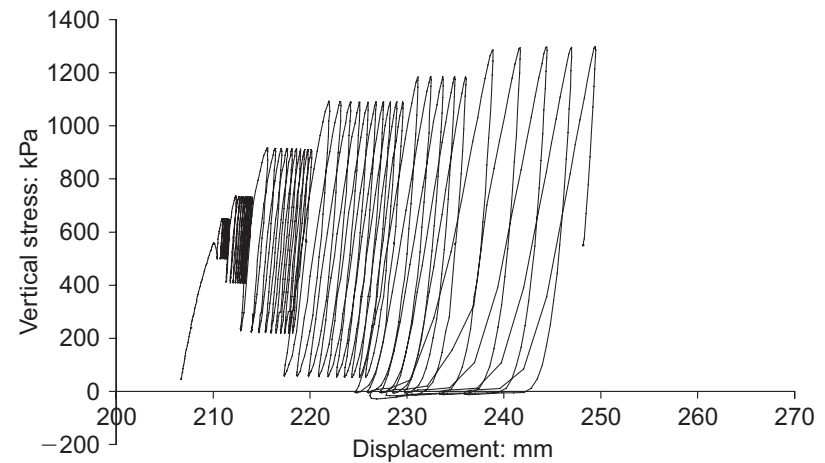

(a)

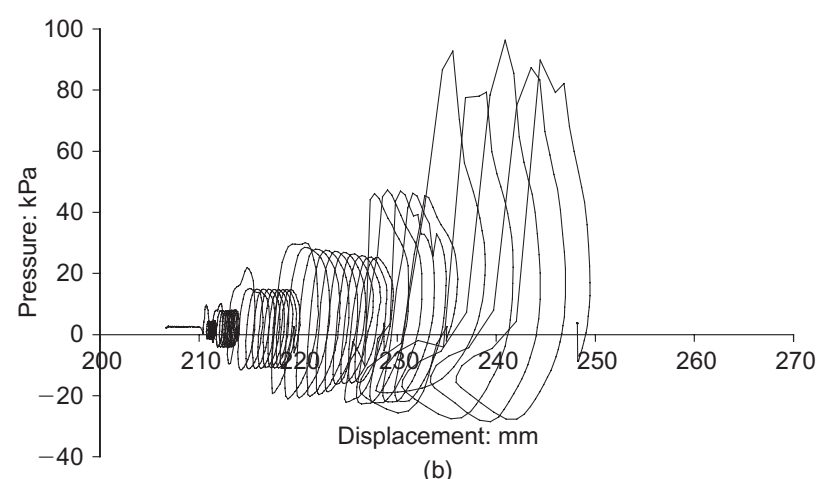

(b)

Fig. 5. Test 2 in Redhill 110 sand at $1 \mathrm{~Hz}$ and $0 \mathrm{kPa}$ ambient pressure: (a) vertical stress; (b) lid water pressure

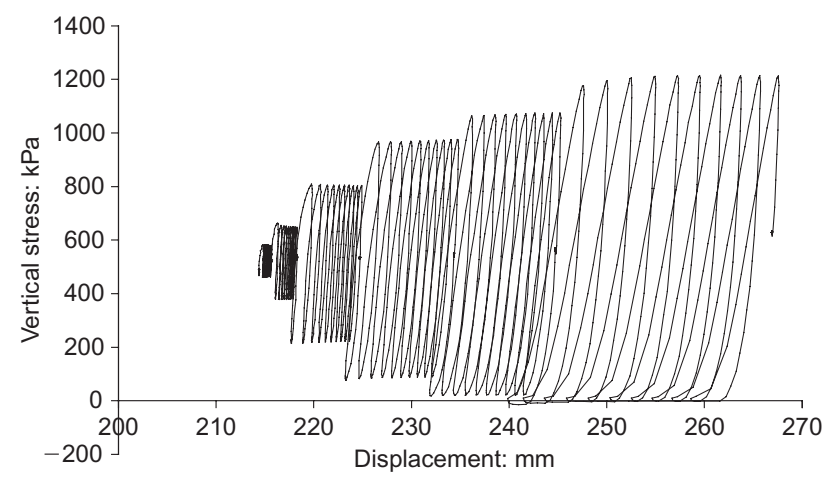

(a)

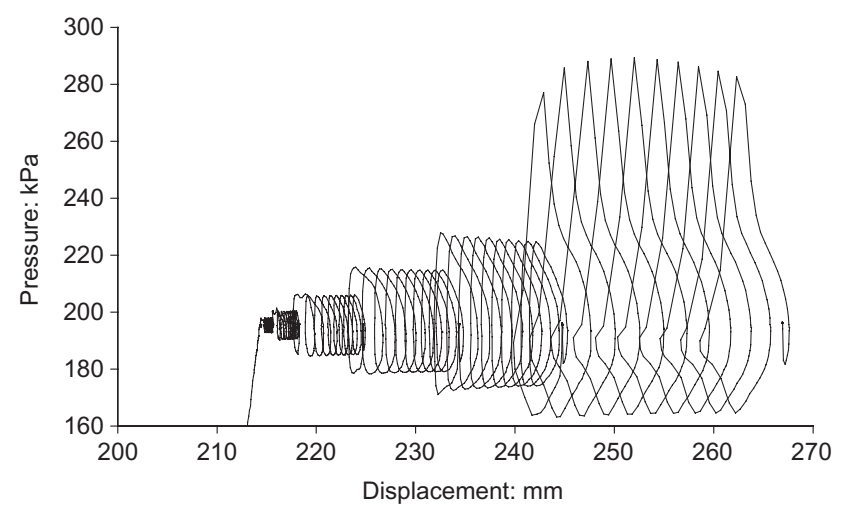

(b)

Fig. 6. Test 6 in Redhill 110 sand at $1 \mathrm{~Hz}$ and $200 \mathrm{kPa}$ ambient pressure: (a) vertical stress; (b) lid water pressure

increased all water pressures by $200 \mathrm{kPa}$. This is exactly as one would expect from the principle of effective stress, in the absence of cavitation, and is therefore indirect evidence that cavitation did not occur during these cyclic tests. Minor differences between the two tests are mainly attributable to the fact that: (a) in Test 6 , ten rather than five cycles were carried out in each of the last two cycling packages; (b) the vertical loads in Test 2 are slightly higher, and (c) the relative density of the sand in Test 6 is slightly lower.

The measured water pressure under the caisson lid (Figs 5(b) and 6(b)) shows that the pressure amplitude increased with the load amplitude. The changes in pressure (the difference between the maximum and minimum pressures in a cycle) are plotted against the corresponding values for change in vertical stress in Fig. 7, which shows averaged data for each packet of cycles. The data show a near identical pressure-stress response for the two tests, indicating that the magnitude of the ambient pressure had little influence, as noted above. The pressures generated during the tests were small, typically about $4.4 \%$ of the applied vertical stress, although there is non-linearity in the pressure-stress relationship, with higher pressure ratios at larger amplitudes. However, Fig. 7 compares only amplitudes, and gives no indication of phase, which is discussed further below.

The water pressure measured at the skirt tip in Test 6 is compared with the lid pressure in Fig. 8. The excess pressure at the skirt tip is a small proportion of that measured at the lid. This was typical of all tests where the skirt tip water pressure was recorded.

Data from multiple-amplitude cyclic tests in HPF5 sand at different loading frequencies are presented in Figs 9-11, showing tests at $0.1 \mathrm{~Hz}, 1 \mathrm{~Hz}$ and $10 \mathrm{~Hz}$ respectively. Differences of up to $15 \%$ in the load amplitudes applied are linked to the performance of the load control system at different frequencies: at the higher rates it is difficult to track the loads, especially for the large-amplitude cycles. In particular, in Test 21 (Fig. 11) the loading does not go into tension,

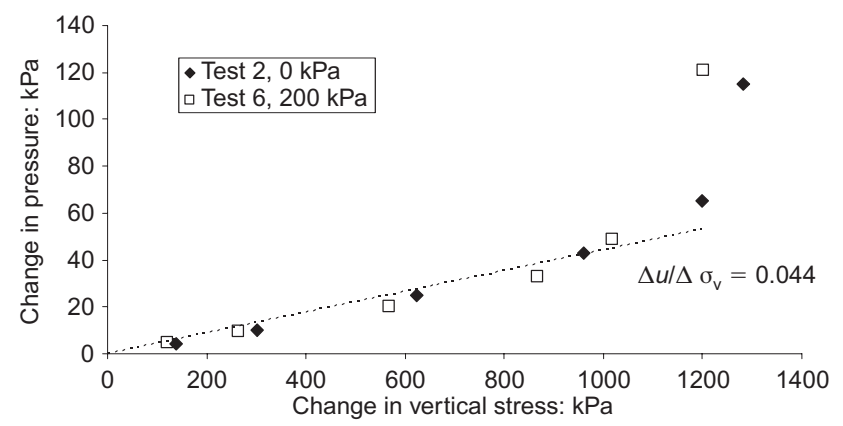

Fig. 7. Change in pore pressure during loading for Tests 2 and 6

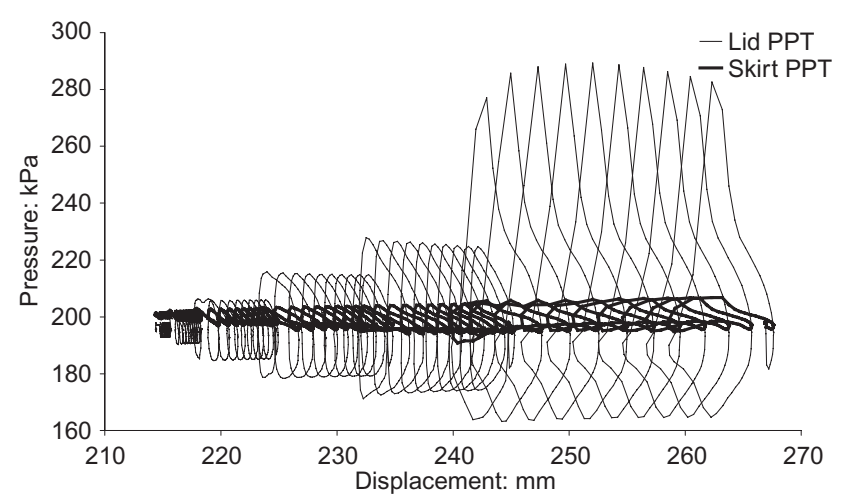

Fig. 8. Pressure at skirt tip compared with pressure beneath lid of caisson in Test 6 


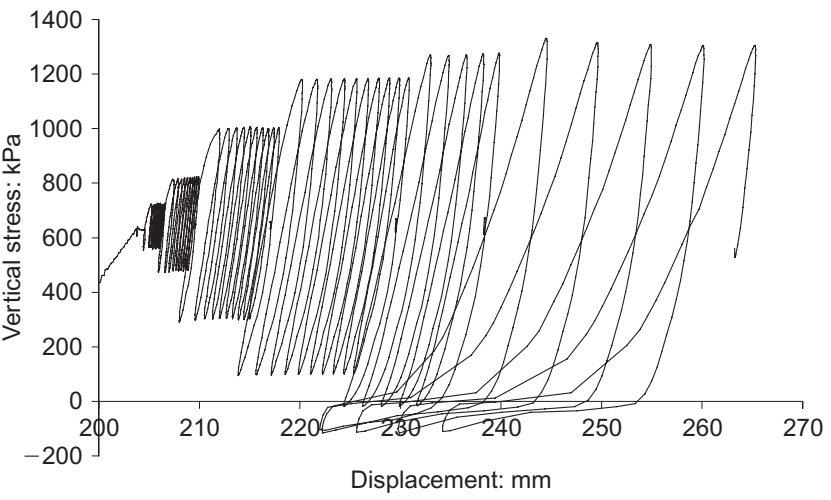

(a)

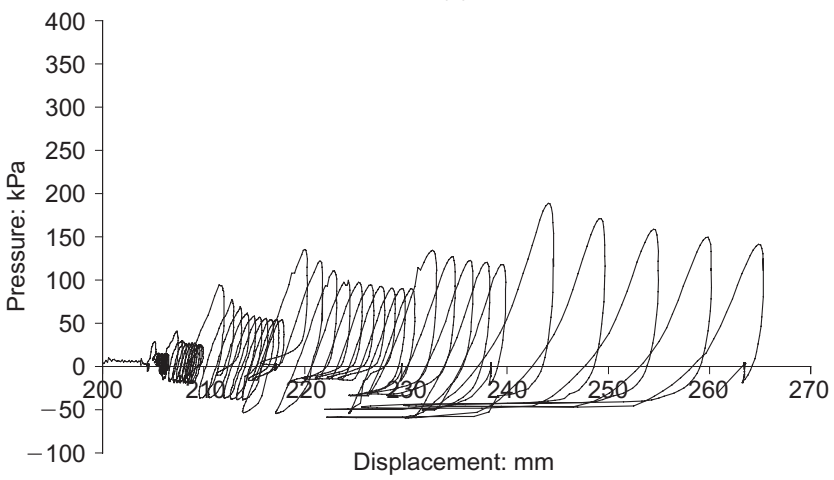

(b)

Fig. 9. Test 15 in HPF5 sand at $0 \cdot 1 \mathrm{~Hz}$ and $0 \mathrm{kPa}$ ambient pressure: (a) vertical stress; (b) lid water pressure

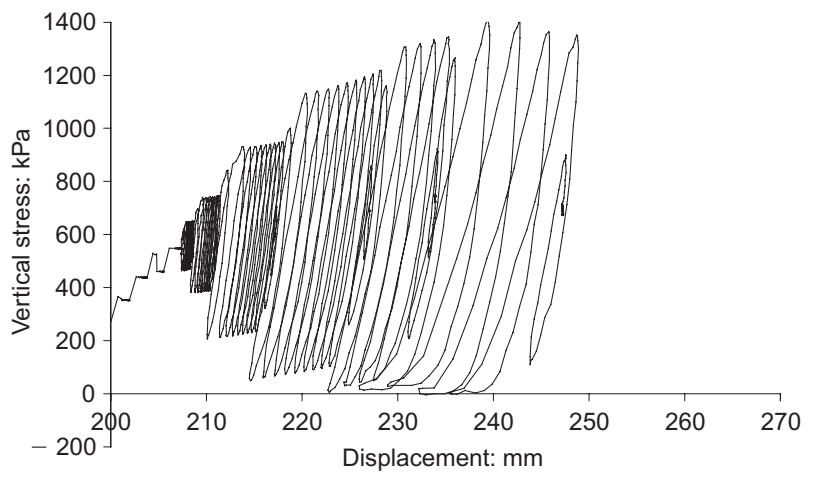

(a)

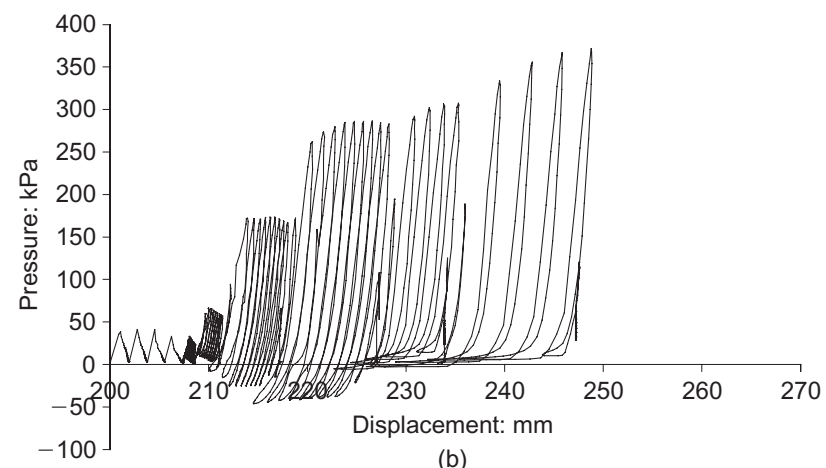

Fig. 10. Test 14 in HPF5 sand at $1 \mathrm{~Hz}$ and $0 \mathrm{kPa}$ ambient pressure: (a) vertical stress; (b) lid water pressure

and there is a consequent impact on the displacement response for this test. However, for the cyclic packages with positive loads, there is evidence that, as the rate of loading increased, the overall penetration of the caisson decreased:

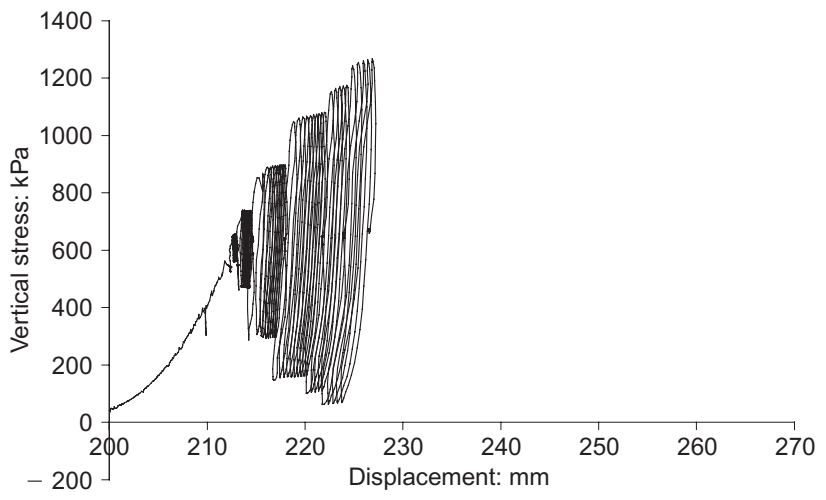

(a)

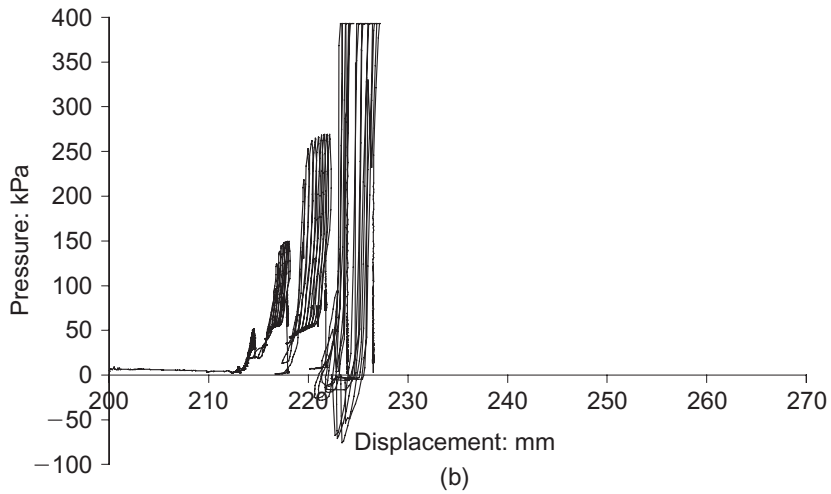

(b)

Fig. 11. Test 21 in HPF5 sand at $10 \mathrm{~Hz}$ and $0 \mathrm{kPa}$ ambient pressure: (a) vertical stress; (b) lid water pressure

the accumulated deformations were much smaller. The stiffness during individual cycles is examined in more detail later. At higher frequencies the pressure response increased. The recorded pressures shown in Fig. 11(b) are cut off at about $400 \mathrm{kPa}$, which was the maximum range of the sensor.

The change in pressure is plotted against change in vertical stress in Fig. 12. Approximately linear trends between pressure and stress could be identified for the tests conducted at $0 \cdot 1 \mathrm{~Hz}$ and $1 \mathrm{~Hz}$. The pressure is about $15 \%$ of the vertical stress in the $0 \cdot 1 \mathrm{~Hz}$ test and $25 \%$ for the $1 \mathrm{~Hz}$ test. The pressure is much higher in these tests than the $4.4 \%$ recorded in the coarser Redhill 110 sand, because the permeability of the HPF5 sand is about three orders of magnitude less than that of Redhill 110. For the test at $10 \mathrm{~Hz}$ the relationship between pressure and stress is strongly non-linear, but it is just possible that this result has been affected by the response time of the pressure transducer. There is, however, a consistent trend that the measured

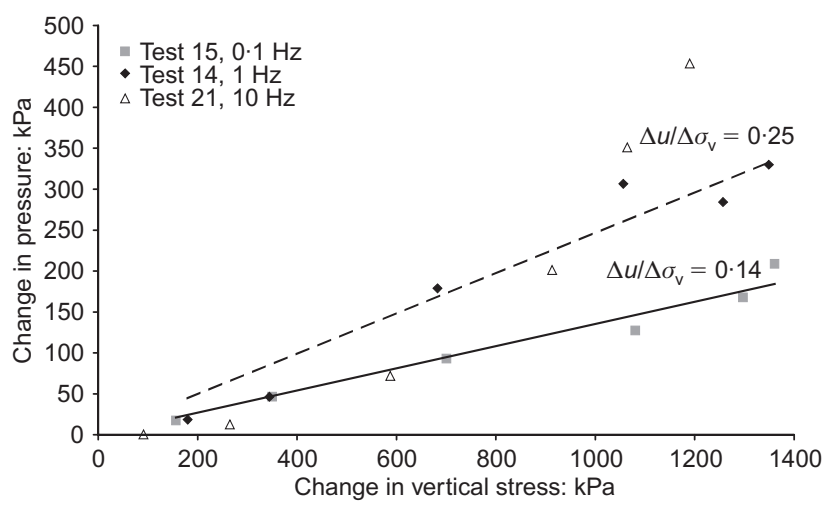

Fig. 12. Change in pore pressure during loading for Tests 14,15 and 21 
pore pressures are larger at higher rates of cycling and for a less permeable sand.

This may seem, at first sight, an entirely expected observation. However, it is useful to consider the mechanisms occurring within the soil around the foundation. The problem is one of transient loading to a large body of soil where, importantly, partial drainage occurs (i.e. the soil is neither fully undrained nor drained). Load application will increase the mean stress immediately below the footing, leading to an increase in excess pore water pressure. Clearly, the faster the load is applied, relative to the permeability of the sand, the greater the ratio of $\Delta u / \Delta \sigma_{\mathrm{v}}$ will be expected. However, the soil will also shear to sustain the applied load. In dense sand this shearing leads to dilation, and if this is suppressed owing to insufficient inflow of water, negative excess pressures will occur. The faster the load application, the higher the negative excess pressures in dilating zones. The different excess pressures at different locations will lead to flow, and the pressures measured at discrete points will reflect, in some way, a balance between conflicting mechanisms. Higher loads will lead both to a higher mean stress and also to greater shearing of the soil, and therefore to higher negative excess pressures. To assess these interactions fully would require measuring water pressures at a number of points in a radial plane through the soil.

Bearing in mind the above comments, it is possible to assess qualitatively the degree of drainage. For drained sands the pressure can be related to the velocity of the caisson through Darcy's law (e.g. Houlsby et al., 2005), whereas for undrained conditions the pressure would be expected to be related to the displacement. By examining the relative phases of the displacement, velocity, stress and pressure in the cycles, it is possible to gauge the degree of drainage. The phase has been obtained by fitting sinusoids to the relevant signals for the fourth cyclic load packet in Tests 6 , 14, 15 and 21, and the results are shown in Table 4. The phase angles in Table 4 are calculated relative to the displacement: that is, the phase angle for displacement is taken as zero. The computed phase for the velocity ranged from $86^{\circ}$ to $88^{\circ}$, which is close to the theoretical $90^{\circ}$ (the small difference being due to the fact that neither the displacement nor the velocity varies purely sinusoidally with time). The pressure was found to be approximately in phase with the velocity in Test 6, in Redhill 110 sand, but closer to the phase of the displacement in the tests conducted in the finer HPF5 sand. Furthermore, in HPF5 sand, as the cyclic loading rate increased the pressure was more closely in phase with the displacement. These results suggest that the tests in Redhill 110 were in the drained to partially drained range whereas the tests in HPF5 approached undrained behaviour. Sinusoidal curves were also fitted to plots of effective load (defined as the applied load minus the load due to the pore pressure, $V^{\prime}=V-u A$ ) with time. The results are also presented in Table 4 . The effective load was broadly in phase with the displacement for all tests, as would be expected. Differences in phase between effective load and displacement could be due to viscous damping and dynamic loading, and the faster tests in HPF5 show more phase difference. This may be related to the fact that the change in pressure was not linear with the change in vertical stress (Fig. 12).

Definitions of cyclic unloading stiffness and incremental displacement are shown in Fig. 13. The variation of the unloading stiffness is plotted in Fig. 14 against the number of cycles for each amplitude of loading applied in Test 6. The unloading stiffness increased with the number of cycles, although at decreasing rate, during the $\pm 5 \mathrm{kN}( \pm 81 \mathrm{kPa})$, $\pm 10 \mathrm{kN}( \pm 162 \mathrm{kPa})$ and $\pm 20 \mathrm{kN}( \pm 325 \mathrm{kPa})$ load packets. The unloading stiffness was almost constant during cyclic load packets in excess of $\pm 20 \mathrm{kN}( \pm 325 \mathrm{kPa})$, with the stiffness decreasing as the load amplitude increased. Fig. 15 shows the unloading stiffness over 1000 cycles for Test 12, conducted at $35 \pm 15 \mathrm{kN}(568 \pm 244 \mathrm{kPa})$. The stiffness increased at a very slow, and decreasing, rate throughout the test and could be treated simply as constant without significant error. These observations are important, because they provide no evidence of degradation of stiffness during cycling, but on the contrary indicate constant or increasing stiffness.

Figure 16 shows the incremental and cumulative cyclic displacements during Test 15 . The incremental displacement per cycle decreased with the number of cycles and became small, but positive, after about 200 cycles. About half of the cumulative displacement occurred during the first $200 \mathrm{cy}-$ cles. Further 'ratchetting' of the caisson into the sand then occurred at an almost constant rate per cycle. Such a

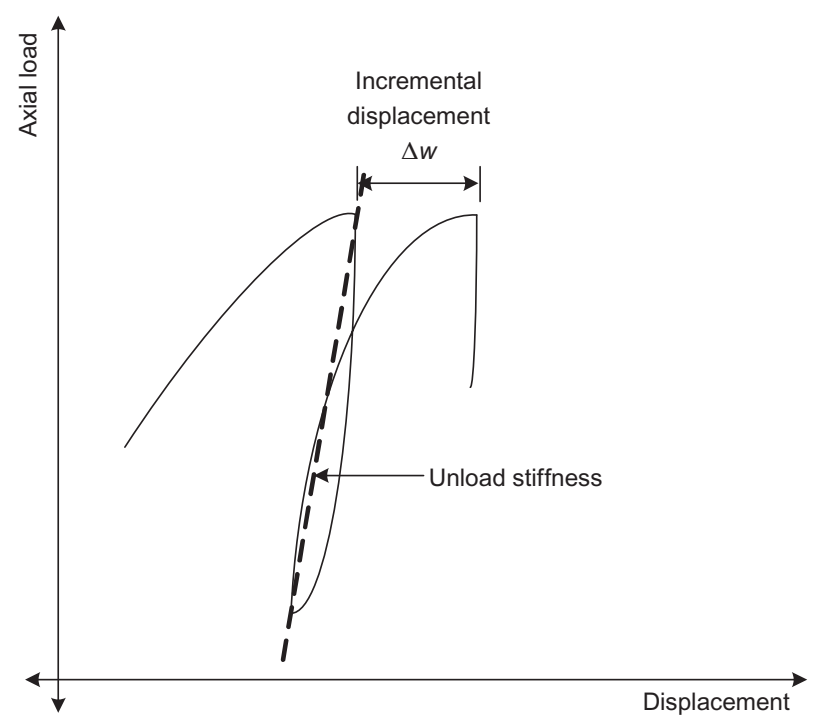

Fig. 13. Definitions of unload stiffness and incremental displacement

Table 4. Amplitude and phase for the fourth cyclic load packet

\begin{tabular}{|c|c|c|c|c|c|c|c|c|c|c|c|c|}
\hline \multirow[t]{2}{*}{ Test } & \multirow[t]{2}{*}{ Sand } & \multirow{2}{*}{$\begin{array}{l}\text { Frequency: } \\
\text { Hz }\end{array}$} & \multicolumn{2}{|c|}{ Displacement } & \multicolumn{2}{|c|}{ Velocity } & \multicolumn{2}{|c|}{ Vertical stress } & \multicolumn{2}{|c|}{ Lid pressure } & \multicolumn{2}{|c|}{ Effective stress } \\
\hline & & & $\begin{array}{l}\text { Amplitude: } \\
\mathrm{mm}\end{array}$ & $\begin{array}{l}\text { Phase:* } \\
\text { degrees }\end{array}$ & $\begin{array}{l}\text { Amplitude: } \\
\mathrm{mm} / \mathrm{s}\end{array}$ & $\begin{array}{l}\text { Phase: } \\
\text { degrees }\end{array}$ & $\begin{array}{l}\text { Amplitude: } \\
\mathrm{kPa}\end{array}$ & $\begin{array}{l}\text { Phase: } \\
\text { degrees }\end{array}$ & $\begin{array}{l}\text { Amplitude: } \\
\qquad \mathrm{kPa}\end{array}$ & $\begin{array}{l}\text { Phase: } \\
\text { degrees }\end{array}$ & $\begin{array}{l}\text { Amplitude: } \\
\mathrm{kPa}\end{array}$ & $\begin{array}{l}\text { Phase: } \\
\text { degrees }\end{array}$ \\
\hline 6 & Redhill & $1 \cdot 0$ & $2 \cdot 7$ & 0 & 17 & 86 & 906 & 25 & 35 & 102 & 898 & 23 \\
\hline 15 & HPF5 & $0 \cdot 1$ & $5 \cdot 3$ & 0 & 3 & 88 & 1096 & 14 & 123 & 26 & 976 & 12 \\
\hline 14 & HPF5 & $1 \cdot 0$ & $5 \cdot 1$ & 0 & 32 & 87 & 1090 & 18 & 322 & 10 & 772 & 21 \\
\hline 21 & HPF5 & $10 \cdot 0$ & $2 \cdot 1$ & 0 & 130 & 86 & 930 & 25 & 206 & 6 & 741 & 30 \\
\hline
\end{tabular}

*Zero by definition: reference phase. 


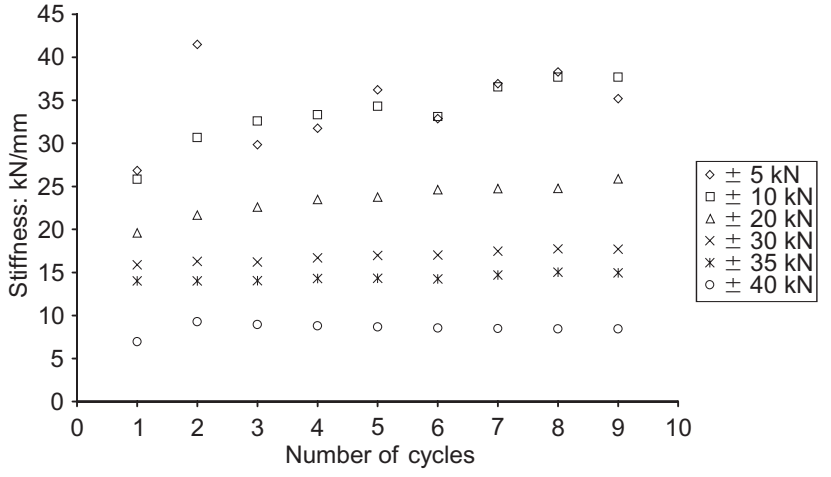

Fig. 14. Variation of unloading stiffness with number of cycles during Test 6 in Redhill 110 sand

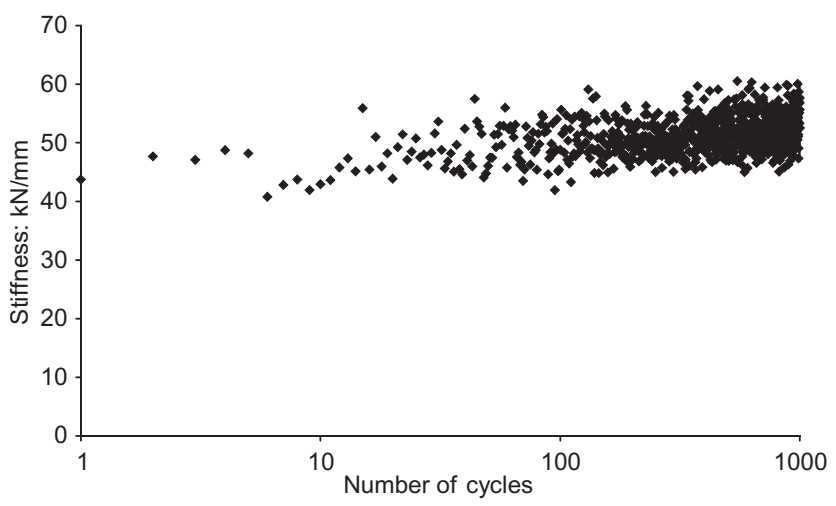

Fig. 15. Unloading stiffness during cycling at $35 \mathrm{kN} \pm 15 \mathrm{kN}$ in Redhill 110 sand

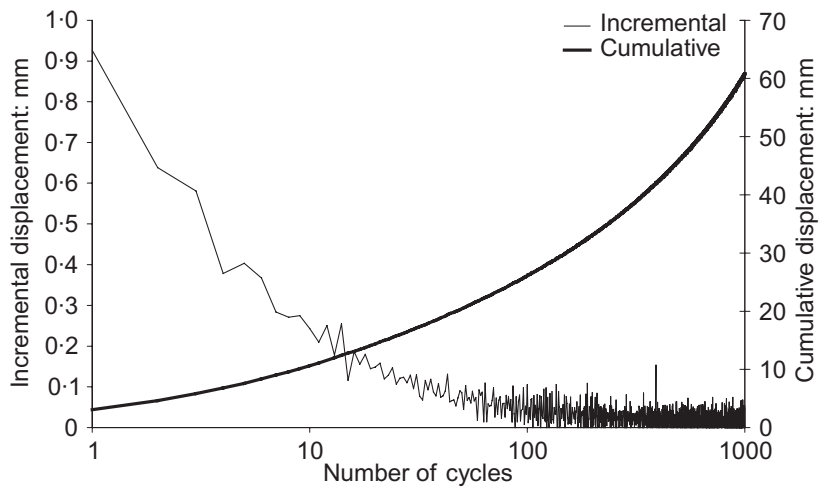

Fig. 16. Incremental and cumulative cyclic displacements

response would be expected to result ultimately in a hardening of the response (as opposed to upward ratchetting movement, which would be of much greater concern to a designer). There are insufficient data, however, to be able to quantify cumulative movements after many cycles.

\section{Ultimate tensile loading}

Figure 17 shows vertical stress data from three pullout tests in Redhill 110 sand. In two tests the caissons were pulled out of the sand at rates of $5 \mathrm{~mm} / \mathrm{s}$ and $100 \mathrm{~mm} / \mathrm{s}$ respectively at atmospheric pressure. The third test was at an ambient pressure of $200 \mathrm{kPa}$ above atmospheric, and pulled out at $100 \mathrm{~mm} / \mathrm{s}$. The arrows on the figure show the direction of movement with time. The data show that the ultimate load increased with the pullout rate and (in stark contrast with the results for cyclic loading) also increased with the

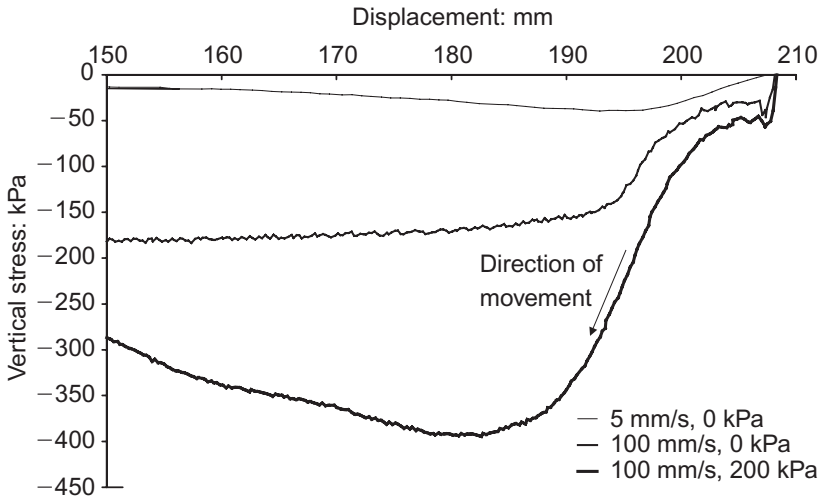

Fig. 17. Ultimate tensile loading in Redhill 110 sand

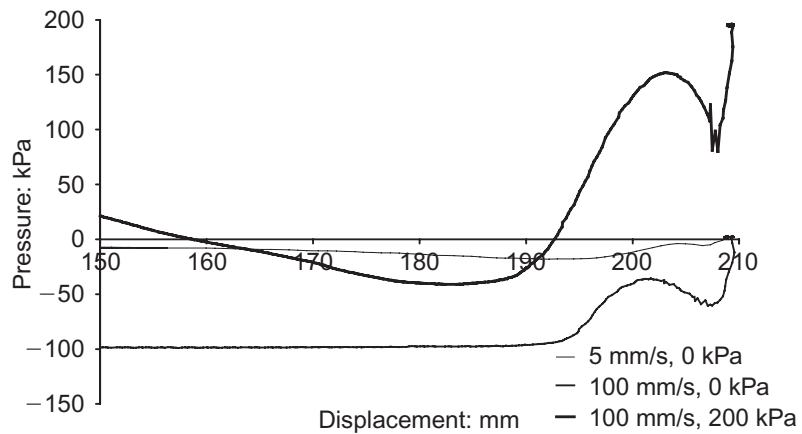

Fig. 18. Pressures beneath lid of caisson during ultimate tensile loading

magnitude of the ambient pressure. The pore pressures during these tests are shown in Fig. 18, showing that the pressure beneath the caisson lid was also dependent on the rate of pullout. A small suction pressure was generated in the test at $5 \mathrm{~mm} / \mathrm{s}$. In contrast the cavitation pressure of $-100 \mathrm{kPa}$ was reached in the test at $100 \mathrm{~mm} / \mathrm{s}$. When the ambient pressure was increased to $200 \mathrm{kPa}$ the cavitation limit (expected to be about $-300 \mathrm{kPa}$ ) was not reached, but a suction of $-250 \mathrm{kPa}$ was generated. Fig. 19 shows suctions beneath the caisson lid and at the skirt tip, along with the net vertical stress on the caisson, and Fig. 20 a detail of the same data plotted against time. Note the distinct change in stiffness of the load-deformation response as the net stress on the caisson changes sign. As the caisson is pulled from the soil a rapid response is initially observed at the lid, but there is little response at the skirt tip ((a) to (b)). A short period later, less than $100 \mathrm{~ms}$ (at (b)), a small pressure drop is observed at the skirt tip, indicating that a pressure front propagates downwards in the caisson. As the load on the

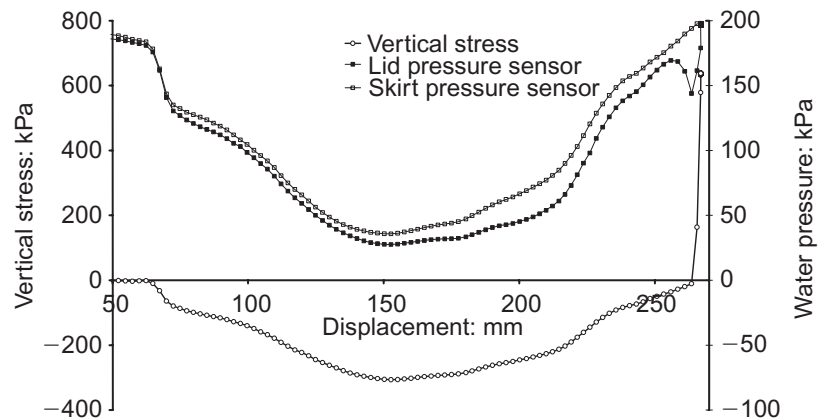

Fig. 19. Pressure at skirt tip and beneath lid of caisson in Test 6 during pullout 


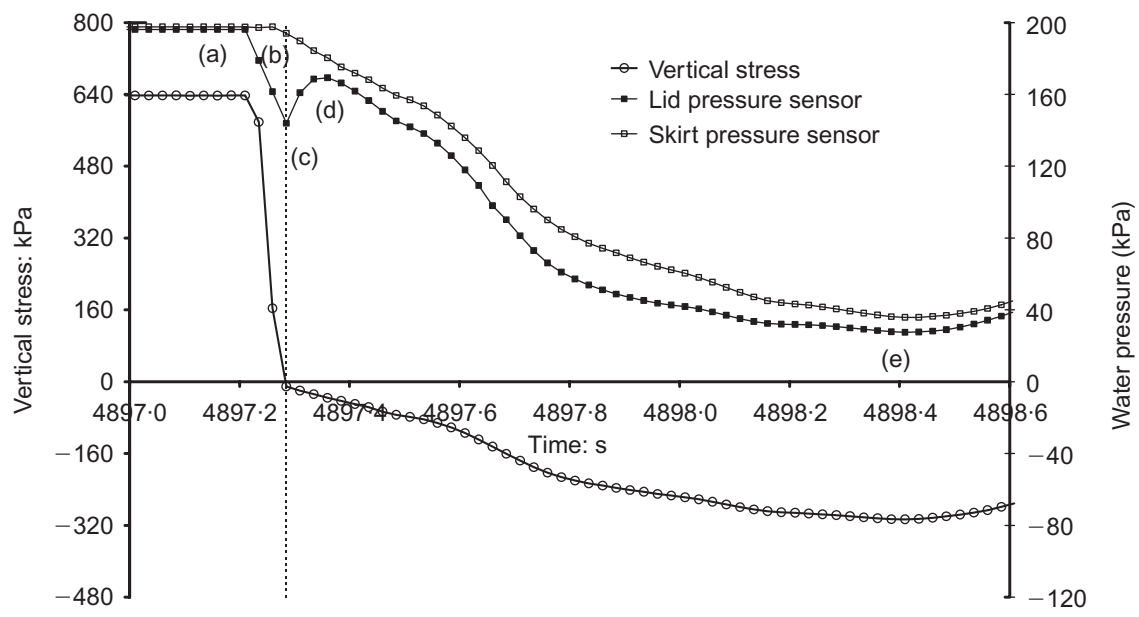

Fig. 20. Water pressures and vertical stress against time for Test 6 during pullout

caisson changes sign the pressure at the lid sensor suddenly increases (at (c)) but the skirt pressure continues reducing, suggesting a change of mechanism (although the detailed mechanics are not clear). Steadier conditions are attained after (d), when the ratio of the skirt to lid excess pressure varies from about 0.8 at (d) to approximately 0.95 at (e).

In Fig. 21, data from Tests 6 and 12, where cycling was carried out prior to pullout, are compared with Test 10 , where the caisson was pushed into the sand and immediately pulled out. Because of the different loading histories, the caisson had penetrated different amounts prior to pullout (Test 6 to $267 \mathrm{~mm}$, Test 10 to $211 \mathrm{~mm}$ and Test 12 to $240 \mathrm{~mm}$ ). For comparison, the start of each pullout has been rebased to $250 \mathrm{~mm}$. The tests were all conducted at an ambient pressure of $200 \mathrm{kPa}$ in Redhill 110 sand. The ultimate tensile vertical stress after each of the cyclic tests was less than in Test 10, but this ultimate tensile vertical stress was, however, directly related to the ultimate suction pressure in each test. The ultimate suction pressures were smaller in the tests where cycling was applied than in Test 10. The softened response from the caissons with the significant cyclic loading histories indicates that cycling may have caused loosening on potential failure planes. This is supported by the fact that the ultimate capacity in Test 10 (without cycling) was mobilised at a smaller tensile displacement than for the tests with cycling. No direct measurement of the soil density during the test was possible, nor was any assessment of heave around the foundation performed. It is therefore not possible at this stage to state whether the soil became globally denser or looser during cycling, in spite of the fact that net downward movement of the caisson had occurred.

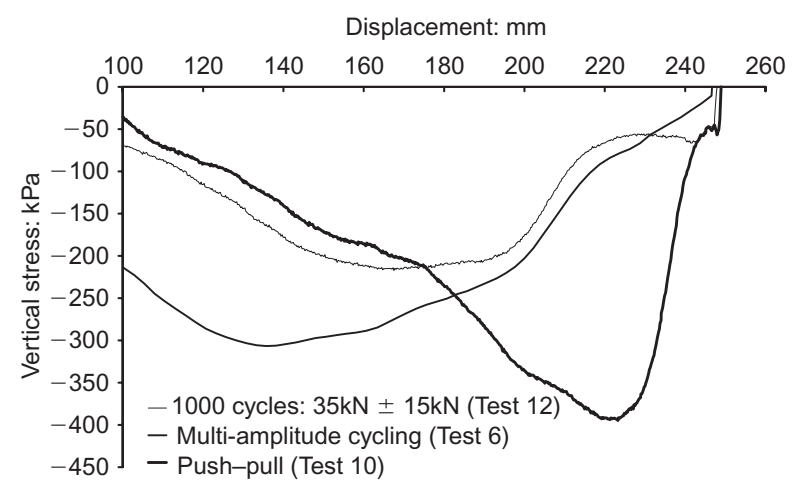

Fig. 21. Degradation of ultimate tensile capacity after cyclic loading

\section{IMPLICATIONS FOR PROTOTYPE FOUNDATIONS \\ Serviceability loading}

The transient tensile capacity of a skirted foundation depends on a complex interaction between the permeability of the soil, the length of the drainage path and the rate of loading. A non-dimensional parameter that incorporates these variables is $T_{\mathrm{v}}$, the time parameter used in one-dimensional consolidation analysis given by

$$
T_{\mathrm{v}}=c_{\mathrm{v}} \frac{t}{H^{2}}
$$

where $c_{\mathrm{v}}=k /\left(\gamma_{\mathrm{w}} m_{\mathrm{v}}\right)$ is the coefficient of consolidation, $k$ is the permeability of the sand, $m_{\mathrm{v}}$ is the inverse of the constrained modulus of the sand, $\gamma_{\mathrm{w}}$ is the unit weight of water, $t$ is the time taken for a specified degree of pore pressure dissipation, and $H$ is the length of the drainage path. If it is assumed that the constrained modulus is proportional to the square root of the mean vertical stress in the sand beneath the caisson, and that the mean vertical stress and $H$ are both proportional to the diameter of the caisson then it follows that, for comparable degrees of consolidation in model and prototype,

$$
\frac{k_{\mathrm{m}}}{k_{\mathrm{p}}}=\frac{t_{\mathrm{p}}}{t_{\mathrm{m}}}\left(\frac{D_{\mathrm{m}}}{D_{\mathrm{p}}}\right)^{3 / 2}
$$

where $k_{\mathrm{m}}$ and $k_{\mathrm{p}}$ are the permeabilities of the model and prototype sands, $D_{\mathrm{m}}$ and $D_{\mathrm{p}}$ are the diameters of the model and prototype caissons, and $t_{\mathrm{m}}$ and $t_{\mathrm{p}}$ are the periods of loading on the model and prototype caissons. Equation (2) can be used to infer the behaviour of prototype-scale caissons from the model-scale test data.

The diameter and skirt length of caissons in a full-scale tetrapod foundation supporting an offshore wind turbine might be of the order of $6 \mathrm{~m}$ and $4 \mathrm{~m}$ respectively. The relevant period of wave loading in UK coastal waters is in the order of $7 \mathrm{~s}(\sim 0 \cdot 14 \mathrm{~Hz})$. A typical permeability of a sand in offshore locations around the UK may be of the order of $0.001 \mathrm{~m} / \mathrm{s}$ (but clearly with a rather wide variation). From equation (2), the rate of loading in the laboratory required to simulate these field conditions was $7 \mathrm{~Hz}$ for Redhill 110 sand and $0.007 \mathrm{~Hz}$ for HPF5. Based on these values, the tests in Redhill 110 are the more relevant than the tests in HPF5 for this case. In the field, caissons are therefore likely to be loaded in partially drained to drained conditions.

The laboratory tests conducted in HPF5 sand showed that large transient pore water pressures were generated beneath the caisson lid when the caisson was loaded at rates of $1 \mathrm{~Hz}$ and above. There was no evidence of pressure accumulation 
during these tests, but only a few cycles were applied. The limited model data suggest that accumulation of pore pressure within the caissons will not occur at prototype scale. If, however, there is an accumulation of pore pressure, greater deformations of the caissons can be expected. A method such as that proposed by Bye et al. (1995) could be employed to estimate the accumulation of pore pressure, and design the caisson so that the total vertical load minus the load due to positive pore pressure does not approach $0 \mathrm{kN}$ on the upwind foundation of the tetrapod.

Recent analyses suggest that foundations for offshore wind turbines will need to be designed to exceed a stiffness criterion, rather than to resist an ultimate load case. This requirement allows the structural stiffness of the turbine structure to be tuned to keep it within a narrow frequency range. The data from the cyclic tests suggest that, as long as the total vertical load does not approach $0 \mathrm{kN}$, then the stiffness of the foundation will increase with the number of cycles. The largest deformations are likely to occur during the first significant loading event after installation. The size and spacing of the caissons in a tetrapod foundation should be designed to limit the load on the upwind leg to $0 \mathrm{kN}$ at worst, and preferably a slight compressive load, to minimise vertical deformations of the caissons under serviceability loading conditions. Kelly et al. (2006a) discuss in detail the issue of scaling of stiffness between model and prototype, using evidence from larger-scale field trials.

\section{DESIGN FOR AN ULTIMATE TENSILE LOAD}

One might wish to design the spacing and diameter of caissons to resist an ultimate tensile load during an extreme storm event with a long return period. The model data suggest that large tensile loads can be attained under certain conditions. Furthermore, over the period of a cycle, if the mean load is compressive and the caisson does not fail in tension, the net deformation will be downward. The model data indicate that the ultimate tensile load is dependent on the suction pressure that can be generated beneath the lid of the caisson during tensile loading. This will be greatest in deeper water, in fine-grained sand, and when the rate of tensile loading is fast. However, the data also indicate that large tensions are possible only after significant displacements have occurred, which may render the structure unserviceable after loading.

Houlsby et al. (2005) present equations that allow the ultimate tensile load and suction pressures in sand to be predicted. For example, when a caisson is pulled out sufficiently rapidly to cause the pore water to cavitate, the ultimate tensile load can be computed using case (d) in Houlsby et al. (2005). The ultimate tensile load in this case is given by

$$
V=-s A\left\{1+\left(\frac{4 Z^{2}}{D h}\right)\left[\exp \left(-\frac{h}{Z}\right)-1+\frac{h}{Z}\right] K \tan \delta\right\}
$$

where $V$ is the ultimate tensile load, $s$ is the suction pressure, $A$ is the cross-sectional area of the caisson, $Z$ is defined as $Z$ $=D\left(m^{2}-1\right) /(4 K \tan \delta), m$ is a load-spreading parameter, $h$ is the installed length of the caisson skirts, $D$ is the diameter of the caisson, $K$ is the lateral earth pressure coefficient, and $\delta$ is the sand/skirt interface friction angle. The variation with time of the ultimate vertical stress and suction pressure for Test 16 (in HPF5 sand, at atmospheric pressure, and pulled out at a rate of $100 \mathrm{~mm} / \mathrm{s}$ ), and an estimate of the tensile stress using equation (3), are shown in Fig. 22. The cavitation limit was reached in this test and the suction pressure was about $-100 \mathrm{kPa}$. The vertical stress was calculated

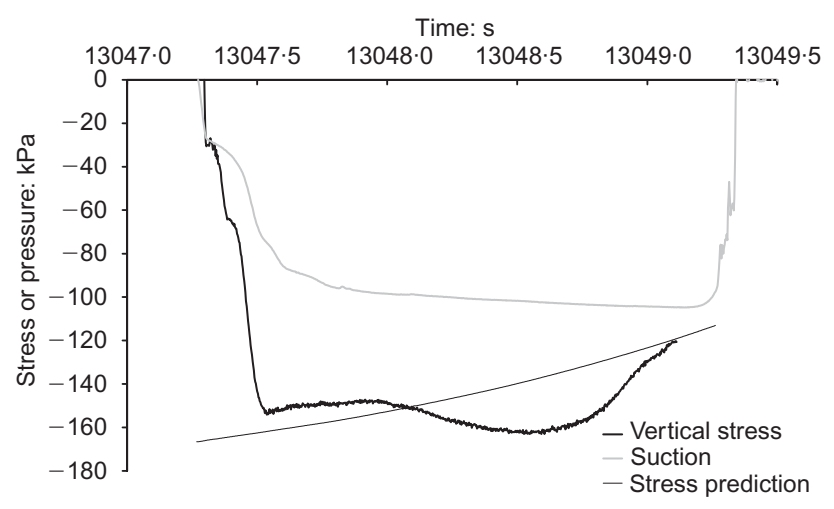

Fig. 22. Prediction of components of ultimate tensile load in Test 16

using the parameter values given in Houlsby et al. (2005) of $K \tan \delta=0.7$ and $m=1.5$. Aside from minor differences prior to the full cavitation pressure being reached, the ultimate vertical stress is predicted reasonably well. Houlsby et al. (2005) show that this approach is also successful for caissons pulled out at different rates, in different sands, and subject to different ambient pressures. These analyses provide a framework for predicting the ultimate tensile load. However, note that this was shown to reduce after the caisson had been cycled (see Fig. 21). Thus there is considerable uncertainty involved in designing caissons to withstand tensile loads (other than drained friction), and such a design could not be recommended at this time.

\section{CONCLUSIONS}

Data have been presented from vertical loading tests of model caissons in sand. The tests were conducted in a pressure vessel to simulate the effects of water depth, and were designed to investigate the serviceability and ultimate tensile loading of vertically loaded caisson foundations. The indicated results are as follows.

(a) The ultimate tensile load can be estimated if the suction pressures beneath the caisson are known. However, these suction pressures result from a complex interaction between the rate of loading, the ambient pressure conditions, the soil type and the load history.

(b) The magnitude of the ambient pressure has little or no effect on the deformations of the caisson during cyclic loading, as expected from an effective stress analysis. In contrast, the magnitude of the ambient pressure increases the ultimate tensile load available, owing to its effect on the relative pressure at which cavitation occurs.

(c) Under cyclic loading the magnitudes of the pore pressures within the soil are relatively small, and indicative of partial drainage conditions. As the rate of cycling increases, the positive pore pressures beneath the caisson increase, as does the vertical stiffness of the caisson.

(d) Further work is required to quantify cumulative displacements during cycling.

\section{ACKNOWLEDGEMENTS}

This research was sponsored by the EPSRC, DTI and a consortium of companies (Fugro Ltd, SLP Engineering Ltd, Garrad Hassan, GE Wind Ltd, NEG Micon and Shell Renewables Ltd). 


\section{REFERENCES}

Bye, A., Erbrich, C., Rognlien, B. \& Tjelta, T. I. (1995). Geotechnical design of bucket foundations. Paper OTC 7793. Offshore Technology Conference, Houston, pp. 897-908.

Byrne, B. W. \& Houlsby, G. T. (2002). Experimental investigations of the response of suction caissons to transient vertical loading. Proc. ASCE, J. Geotech. Engng 128, No. 11, 926-939.

Byrne, B. W. \& Houlsby, G. T. (2003). Foundations for offshore wind turbines. Phil. Trans. R. Soc. London Ser. A 361, No. 813, $2909-2930$.

Byrne, B. W., Houlsby, G. T., Martin, C. M. \& Fish, P. M. (2002). Suction caisson foundations for offshore wind turbines. Wind Engng 26, No. 3, 145-155.

Houlsby, G. T., Kelly, R. B. \& Byrne, B. W. (2005). The tensile capacity of suction caissons in sand under rapid loading. Proceedings of the international symposium on frontiers in offshore geomechanics, Perth, pp. 405-410.

Houlsby, G. T., Kelly, R. B., Huxtable, J. \& Byrne, B. W. (2006). Field trials of suction caissons in sand for offshore wind turbine foundations. Géotechnique 56, No. 1, 3-10.

Kelly, R. B., Byrne, B. W., Houlsby, G. T. \& Martin, C. M. (2003).
Pressure chamber testing of model caisson foundations in sand. Proceedings of the international conference on foundations, Dundee, pp. 421-431.

Kelly, R. B., Byrne, B. W., Houlsby, G. T. \& Martin, C. M. (2004). Tensile loading of model caisson foundations for structures on sand. Proc. ISOPE, Toulon 2, 638-641.

Kelly, R. B., Houlsby, G. T. \& Byrne, B. W. (2006a). A comparison of field and laboratory tests of caisson foundations in sand and clay. Géotechnique, 56, No. 9, 617-626.

Kelly, R. B., Houlsby, G. T. \& Byrne, B. W. (2006b). Transient vertical loading of model suction caissons in a pressure chamber, Report OUEL 2291/06. Department of Engineering Science, University of Oxford.

McManus, K. J. \& Davis, R. O. (1997). Dilation induced pore fluid cavitation in sands. Géotechnique 47, No. 1, 173-178.

Tjelta, T. I. (1994). Geotechnical aspects of bucket foundations replacing piles for the Europipe 16/11-E Jacket. Paper OTC 7379, Offshore Technology Conference, Houston, pp. 73-80.

Tjelta, T. I. (1995). Geotechnical experience from the installation of the Europipe Jacket with bucket foundations. Paper OTC 7795. Offshore Technology Conference, Houston, pp. 897-908. 